Bejo Sutrisno and Matresia Apriliani

Depiction of Princess Merida in Disney princess movie "Brave"

\title{
DEPICTION OF PRINCESS MERIDA IN DISNEY PRINCESS MOVIE "BRAVE" DIRECTED BY MARK ANDREWS AND BRENDA CHAPMAN
}

\author{
Bejo Sutrisno \\ Sekolah Tinggi Bahasa Asing- IEC Jakarta \\ bejo@stibaiec-jakarta.ac.id \\ Matresia Apriliana \\ Sekolah Tinggi Bahasa Asing- IEC Jakarta \\ $\underline{\text { matresia_apriliani@gmail.com }}$
}

Sutrisno, B., and Apriliana, M. (2020). Depiction of Princess Merida in Disney Princess movie "Brave" directed by Mark Andrews and Brenda Chapman. Journal of English Language and literature, 5(1), 89-96. DOI 10.37110/jell.v5i01.98

Received: 11-01-2020

Accepted: 20-02-2020

Published:01-03-2020

\begin{abstract}
This study discusses the depiction of Princess Merida. The objectives of the research are to find out what kind of characteristics that represent Princess Merida and to find out how the characteristics that Princess Merida has made her special from other Disney Princesses. Qualitative method is used in this research. Data collection in analyzing movie Brave is used by watching the movie repeatedly, reading the summary, making synopsis, taking some notes, understanding the script, identifying the words or dialogues, reading some journals or articles and finding some references on the internet related to the analysis. The research questions are focused on analyzing the characteristics of Princess Merida. The research questions are to find: (1) the kind of characteristics that represent Princess Merida and (2) the characteristics that Princess Merida has makes her special from other Disney Princesses. From those research questions, the writer found that this research exposes how Brave movie represented princess seen from Princess Merida's characters, habits, and appearance by showing the evidence through pictures and dialogues in the movie.
\end{abstract}

Keywords : representation; depiction; disney, Princess Merida, Character.

\section{INTRODUCTION}

Literary work is born from the background and the basic human impulse to express its existence. As expression of reality of life, the context in literary work is structured regularly also interesting. The language in the form of texts composed through the reflection of experience and knowledge potentially have various forms of life representation. Literary work is often also presented in the form of audio visual such as movie.

Movie as a new object of literary study basically has some similarities with another literary works such as poetry, drama, and prose.
Boggs and Petrie (2008) stated that specially as poetry, film communicates through $\mathrm{i}$ magery, metaphor and symbolism.

Such as the drama, film visually and verbally co mmunicates; visually, through action and gesture; verbally, through dialogue. Like the novel, Ultimately, like the novel, film expands or compresses time and space, flowing freely within its broad boundaries."

Based on the phenomenon that occurs, there is a privilege in a literary work. There are various properties which can be studied with a theory. One of them is the theory about character in movie. 
Recent ideas by Janovsky (2018) that all stories must have certain characteristics or elements. Without these elements, any piece of literature would cease to make sense or serve a purpose. For example, stories must have a plot, or events that take place. Another essential story element is the character. Character can be defined as any person, animal, or figure represented in a literary work. There are many types of characters that exist in literature, each with its own development and function.

One of the works of literature with audio visual format that can be studied is the Disney movie "Brave" directed by Brenda Chapman.

However, far too little attention has been paid to Freedman (2001) that one could argue that all feminist call for changes in the social, economic, political, or cultural order, to reduce and eventually overcome this discrimination against women.

The objectives of this research are to find out what kind of characteristics that represent Princess Merida and to find out how the characteristics that Princess Merida has makes her special from other Disney Princesses.

\section{REVIEW OF LITERATURE}

There are five elements presents in all films: plot, emotional effect or mood, character and style or texture. These are basic elements described on film. Film can visualize from story fiction and played by a figure. A figure in a film or the viewer know it as character, maybe described as actors or actress. Kupperman said that the word personality is sometimes treated interchangeable with character, although is connotations are often very different.

In line with the character, Gill (1995) defined that. character is someone in literary work who has some sort of identity, an identity which is made up by appearance, conversation, action, name and thoughts going in the head."

In addition, according to Laughlin (1989) that a character is often expressed through the actions provided for the reader with clues about the personality of character. Character is term for the people in fiction, the heroes and villains, allies, and enemies, love interest and comic reliefs."
In analyzing utilizes three different types of pairings: stock characters, static and developing character, and flat round character (Bogs \& Petrie, 2008).

\section{Stock Character}

Stock characters are minor characters whose actions are completely predictable or typical of their job or profession. Thus they serve as a natural part of the stage properties like a lamp or a chair might function in a play.

2. Static and Developing Character Static characters remain essentially the same throughout the movie. The action does not have an important effect on their lives (as might generally be the case with the hero of an action or adventure movie). Furthermore, static characters are almost essential to comedy and developing characters are essential to serious drama.

\section{Flat and Round Character}

Flat characters are two dimensional, predictable who lack the complexity and unique qualities associated with physiological depth. While, round characters are three dimensional character complex enough to be able to surprise the reader without losing credibility.

Characterization through appearance is viewing the great deal to do with casting since the minute viewers usually see most actor on the screen, they make certain assumption about tem because of their facial features, dress, physical build and mannerism and the way they move, it's called as characterization through appearance. Than the characterization through the dialogue, characters in film naturally reveal a great deal about themselves by what they say and they say it in other words, the values of character could be interpreted through their word choice when they talk to others characters.

Therefore, Boggs (1991) restated that some important change such as the personality, the attitude, or the point of view of life as the result of the action in the story. On the other side the character which does 
Bejo Sutrisno and Matresia Apriliani

Depiction of Princess Merida in Disney princess movie "Brave"

not have significant changes in the story are called the static character.

Characterization just like writer has been said above, that character has certain trait following them called characterization. There are many ways to know the characterization's analysis in the film. The characterization can be understood through several ways:

\section{Characterization through appearance}

How the actor look and what kind of clothes he wear is the main aspect of the characterization. These aspects can be displayed with one of miss-en-scene. The techniques use to arrange everything in the film in order to make meaningful frames or shot. The aspects of miss-en-scene are lighting, setting, color, costume and makeup and behavior of figures. The writer would do use the costume and make-up aspect in the discussion because it is easily to identify and become one of characterization of the character that always appears or wear in the movies (for example, Esther costume that he always wearing cloth-bracelet in her hand in the action show her manipulated-identity).

\section{Characterization through dialogue}

In the film, the characters expose themselves by that action and how they talk. The words choices, the tone, the stress of voices express their minds, attitudes and emotions virtually. Furthermore the use of grammar, structure of sentence, vocabulary, and certain dialect reveal social economy level of the character, educational background and the mental processes.

3. Characterization through external action

The characters in the film are instruments of establishing the plot. They have main purpose in the story therefore they will do everything to achieve it. These actions are called motives which reveal their personalities. ${ }^{11}$ It means that the personalities ill decide how the character acts to gain their purposes.

4. Characterization through internal action
Internal action is the character's mind and emotion that contain secrets, unspoken thoughts, daydreams, aspirations, memories, fears, and fantasies. All of them appear usually in the film. The director can illustrate the character's imagination or mind by the technique of shot. And the technique called cinematographic properties. And of the part is angle and distance. It creates the particular visual effect besides that it enhances the definite sense of vigorous or dramatic situation which is being filmed. ${ }^{12}$ Angles of framing divided into three categories: the straighton angle, the high angle, and the low angle. All these categories used to communicate the difference of dramatic information or emotional attitude. ${ }^{13}$ In addition, the filmmaker utilizes the shot of close-up on an unusually sensitive and expressive face to illustrate the inner action of character. ${ }^{14}$ This technique is called by the distance of camera.

5. Characterization through reactions of other characters

The characterization of the character can be observer by the point of view from others characters. Sometimes at the beginning of scene has already demonstrated information about the characterization.

Characterization, in film, is the presentation of the attitudes and the behavior of imagery person in order to make them credible to the author's audience. It means that characterization is the way to presenting the character and make them acceptable to the audience. Actor who represent the character on the stage also take part in characterizing the character with their own interpretation to the character.

\section{METHOD}

The writer chooses Qualitative data collection in analyzing movie Brave by watching the movie repeatedly, reading the summary, making synopsis, taking some notes, understanding the script, identifying the words or dialogues, reading 
some books/e-books or articles and finding some references on the internet related to the analysis. Kaushik (2011) defined that qualitative data collection is a method in which the characteristics, attributes, properties, qualities, etc. of a phenomenon or thing is described. It is the description of data in a language rather than in numbers. This method does not measure the characteristics but describes them.

Meanwhile, Moleong (2005) stated that Qualitative research method is a method of research that has purpose to understand the phenomenon which is experienced by the subject of the research such as behavior, perception, motivation, action, etc. The research is holistically made using a description in the form of words and language at the specific natural context; also using any naturalistic approaches.

\section{FINDING AND DISCUSSION Findings}

\section{The kind of characteristics that represent} Princess Merida

There are some characteristics found that represent Princess Merida. Those characteristics are:

a. Fearless. The bravery in Princess Merida does not only show on her daily activities, but also in the way she chooses her own path in life as she rejects the betrothal between her and the princes. Furthermore, Princess Merida does not need mother fairy or somebody to help her gain her freedom. She fights for what she wants by herself.

b. Caring. The caring of Princess Merida also shows when her mom already changes into a giant bear. Princess Merida and her mom go to the witch cottage to ask the witch to reverse the curse. The care of Princess Merida also shows when she makes breakfast for her mom and teaches her to catch a fish by herself. It shows Princess Merida kindness and care to her mother since she knows that she is the one who makes her mother into a bear. Through their journey, the bond between her and her mother starts to reestablish. The movie shows Princess Merida's caring through her action for taking care of her mother bear.

c. Stubborn. Princess Merida stubbornness is showed when the archery game begins to know who will be the winner that will be Princess Merida's fiancée. She takes part the game also to represent her own kingdom by her own hand because Queen Elinor said that only the first born from each clans can take part in the game and Princess Merida thinks that she also has right to take the contest since she is the first born from her family. The stubbornness of Princess Merida shows by her action in refusing the betrothal and fight for her freedom.

d. Reckless. Through Princess Merida action, Merida is reckless in taking care of her problem. First, she goes to meet the witch and asked her to give her spell to change her mom, which makes her mom change into a giant bear. The second, she dissolves the witch cottage by accident because she is reckless. She should be calm down when the witch gives her the clue how to make her mom changing back into human. Instead she is pours the vial over and over which makes the witch cottage explode and disappears.

e. Mature. This action shows Princess Merida is mature because she admits that everything happen because of her fault, she also confesses her true feeling toward her mom which makes her mom change back into human. Princess Merida mature characteristic can be seen through her action

f. Responsible. The movie shows Princess Merida is responsible through her action in saving her own family and tries to fix everything that she ruins.

\section{The characteristics that Princess Merida has makes her special from other Disney Princesses.}

\section{a. Princess Merida as an Independent Princess}

From the whole story, the writer concludes that Princess Merida is different with other Disney princess in common. She is what she is and she does what she likes and wants. If in most of the Disney princess's story, princess is an obedient person, Princess Merida is not the one. She is a stubborn princess. She chooses her own path in her life by rejecting the betrothal between her and the suitors from three clans. She keeps struggling to get her freedom by persuade her mom to cancel the betrothal, but Queen Elinor 
Bejo Sutrisno and Matresia Apriliani

Depiction of Princess Merida in Disney princess movie "Brave"

does not listen to her. She keeps telling Princess Merida that this is what all princesses do. Queen Elinor teaches her of how to be a perfect princess, but Princess Merida is not doing it seriously. She just does not want to argue with her mom.

After Princess Merida finds a way to change her mom, she makes a terrible mistake by asking help from the witch in the forest which makes her mom changes into a giant bear. At the first time, she does not want being blamed by her mom for what she does, but at the end of the story, she confesses that everything happens because of her fault. She also tries to find a way to change everything back to normal especially to make her mom back into human being, until finally her mom is back to normal because of her struggle. It means that she takes the responsibility for it.

From the explanation above, the writer see the different princess representation in Brave movie. In Disney princess movie classic, a princess who mistreats by somebody will accept her misery life without complaining or not trying to reject it. Besides, Princess Merida who will betroths to one of the suitors tries to refuse the engagement by complaining it to her mother and rebelling to gain her freedom. This kind of bravery is rarely owned by another princess. Also, she tries to find a way to change her fate by herself which shows that she is an independent princess.

\section{a. Princess Merida as an Inattentive Princess}

In many other princess story, a princess is described as a perfect girl. They tend to have a good attitude and well mannered. While in Brave movie, Princess Merida is defined as a manlier princess. It shows through the way Princess Merida walks, the way she eats, and the way she sits. First, from the way Princess Merida walks. that Princess Merida is an inattentive princess seen from the way she eats, sits, and walks. Furthermore, her characteristic is not included as one. She is manlier princess who has her own dreams and does not care with the importance of her kingdom as being a good princess. She would rather catch her dreams to be free and doing archery in her life.

\section{b. Princess Merida as an Unconventional Princess}

After the writer analyze all about the difference of Princess Merida and other Disney classic princesses, the writer identifies that Princess Merida is different because from her characteristic, appearance, and habit, she does not have a princess prototype as the successor princess. She breaks a princess prototype that a princess is domesticated, highly prized by men, naïve, and damsel in distress. Princess Merida shows that she is a princess that can get her own happiness by herself by make an effort in changing her destiny. Even though her mom tries to stereotyping her to make her as a princess in common by teaching her how to be a perfect princess, Princess Merida refused to do it. She chooses her own way of happiness which is by not marrying the prince. In conclusion, Princess Merida is independent in choosing her own destiny, inattentive in her habits, and unconventional from her appearance as a princess.

\section{Discussion \\ The kind of characteristics that represent Princess Merida}

Princes Merida has a different characteristic with other Disney's princess. It shows from her appearance, attitude, and habit. She would rather climb the cliff rather than primp in the mirror. The writer found six characteristics of Princess Merida which are; fearless, care, stubborn, reckless, mature, and responsible. The writer will explain all her characteristic and the characterization in detail in the paragraphs below.

\section{a. Fearless}

Princess Merida is really fearless girl, it shows on her daily activities. She really likes to ride her horse, goes to forest and does her favorite sport, which is archery. She is really good at it, but her mom, Queen Elinor does not like it and forbids her to do that because Merida is a princess. She has to be a feminist girl just like her mom.

Princess Merida is an excellent archer as shows in the picture 1 when she shoots an arrow to the different target, she never miss it and she does it while riding her horse, Angus. This shows Princess Merida bravery. She could ride a horse while doing archery at the same time. 
Furthermore, the text above tells Princess Merida does not like her life as a princess because she has to do lessons and expectation. She really loves doing archery but she cannot do it every time because her mom does not like her being an archer.

Another bravery that Princess Merida shows is when she defeats the giant bear Mor'du. When she tries to find a way to change her mom into normal, the Will $\mathrm{O}$ the Whisp shows her the ancient kingdom which already abandoned. She slips into the throne room and then she finds the giant bear watching her, then she tries to defeat it with her arrow.

\section{b. Caring}

The second characteristic of Princess Merida is that she is a care person. Even though her three siblings are really naughty boys she still loves them. It shows when she gives them their favorite cookies at dinner. The caring of Princess Merida also shows when her mom already changes into a giant bear. Princess Merida and her mom go to the witch cottage to ask the witch to reverse the curse. The care of Princess Merida also shows when she makes breakfast for her mom and teaches her to catch a fish by herself.

Princess Merida has to cook it for her so she can eat it. But because Queen Elinor eats a lot of fish, Princess Merida asks her to go find fish at the river like the bear used to do. She teaches her mom to catch the fish so she can eat fish as much as she wants. At the end, her mom can eat the raw fish by herself and does not need Princess Merida's help to cook it.

\section{c. Stubborn}

The third characteristic of Princess Merida is stubborn. It shows when her mom tells her that there will be a betrothal between her and the suitors from three clans and she totally balks it.

Princess Merida stubbornness is also showed when the archery game begins to know who will be the winner that will be Princess Merida's fiancée. She takes part the game also to represent her own kingdom by her own hand because Queen Elinor said that only the first born from each clans can take part in the game and Princess Merida thinks that she also has right to take the contest since she is the first born from her family.

\section{d. Reckless}

The fourth characteristic of Princess Merida is reckless. When she knows about the betrothal, she refuses it and argues with her mom that she does not want being married with anybody. She is mad with her mom and ripped the tapestry that her mom makes which makes her mom angry and throws Princess Merida's bow into fire. This action leads to disunity between them. Princess Merida runs to the forest and goes to the witch's cottage. She asks the witch to give her spell to change her mother.

\section{e. Mature}

The fifth characteristic of Princess Merida is mature. It shows when she soothes the lords at the big hall which is ready to start the war because of the obscurity of the betrothal.

Another proof that Princess Merida is mature is when she tries to change her mom back into human being at the end of the movie. She puts the tapestry which she already fix, to cover her bear mother's body, but nothing changes.

Queen Elinor is still a bear. Then Princess Merida confesses that everything happens because of her fault and she also declares that she really loves her mom and wants her back while crying.

\section{f. Responsible}

The last characteristic of Princess Merida is responsible. After what she does in the beginning, she tries to find a way to make everything back into normal. First, when her mom changes into the bear, she takes the responsibility in taking care of her mom and finds a way to reverse the curse. The second is when Princess Merida is deputizing her mom to talk to the three clans about what happened and she also calms down the lords of the three clans. The third is when she protects her mom when King Fergus wants to kill her mother because he thinks that Queen Elinor is Mor'du

From Princess Merida's entire characteristic above, the writer concludes that Princess Merida is dissimilar with other Disney's princesses. The movie tells the different princess characteristic through Princess Merida by showing her fearless, care, stubborn, reckless, mature, and responsible action. 
Bejo Sutrisno and Matresia Apriliani

Depiction of Princess Merida in Disney princess movie "Brave"

\section{The characteristics that Princess Merida has makes her special from other Disney Princesses}

In several Disney princess movies, a princess tends to have a beautiful face, has a good character, and also a feminine behavior. Whereas, Princess Merida's characteristic is disparate from it. From the characteristic of Princess Merida in Brave movie that the writer already mentioned in the chapters above, the writer concludes that there are three differences of princess representation. First, a princess can be independent. Second, a princess can be inattentive. And the last, a princess can be unconventional. The writer will explain all of three aspects and shows the evidence on the subchapters below.

\section{Princess Merida as an Independent Princess}

At the end of the story is depicting a happy ending of Princess Merida is not getting marry with charming prince, or whoever who saves her life, as princess classic story at most. Besides, her happy ending is when she finally gets her freedom to choose what she wants to do in life. In the beginning of the movie, Queen Elinor always tries to make Princess Merida be a perfect princess by teaching her how to be one

\section{Princess Merida as an Unconventional Princess}

If we watch several Disney princess movie classic, we will amaze by the appearance of the princess because they have a pretty face and also they are really feminine. While Princess Merida depicted as a masculine princess who likes to ride a horse and does archery. From her appearances, there are distinct differences between Princess Merida and other Disney princesses. First is from Princess Merida's hair. She has a kinky and unruly hair which looks like not well taken care of. The second is from Princess Merida's dress. Princess Merida wears a dark green color which is not attracting people's eyes especially man.

\section{CONCLUSION}

The writer analyzed Brave movie with character and representation theory. Through those theories, the writer revealed the different princess representation seen from Princess Merida characteristic, habits, and also appearance. The writer uses qualitative descriptive method in analyzing the movie. The writer answers the research question by showing the evidence through pictures and dialogues in the movie. The writer uses other resources such as the movie script, books, and journals in doing this research.

The writer confirms that there are different princess representations in Brave movie seen from the main heroine character, Princess Merida. Through her action and dialogues in the movie, the writer concludes that Princess Merida is dissimilar with other Disney princesses. She refuses to conform to the princess stereotype, she takes matters into her own hand, she doesn't rely on anyone else to fix her mistakes, she remains happily single and she rejects that makeover like a boss. Princess Merida is kind of manly princess who break the tradition in her kingdom to gain her freedom in choosing her own destiny. This movie shows that a princess does not always obey the rules. Princess Merida shows that a princess can be what she wants and chooses what she wants to do in life. Furthermore, this movie also tells that marriage is not the reason to get a happy ending. In this movie, Princess Merida gets her happy ending by mending the bond of her family and also her kingdom which makes her family's relationship stronger. It shows how the mother-daughter relationship can be mended through patience, courage and love. Princess Merida happy ending is the freedom she gets by her own effort in persuading her mom to cancel the betrothal for her and the three suitors from each clans. In the end, all the princes and princesses from their kingdom can chooses their own life and love in the right time and place. This all happens because of the struggle of Princess Merida.

This research exposes how Brave movie represented princess seen from Princess Merida's characters, habits, and appearance by 
showing the evidence through pictures and dialogues in the movie.

\section{RFERENCES}

Boggs, J. M and Dennis, W.P. (2008). The art of watching films: Seventh Edition. New York: McGraw Hill

Freedman, J. (2001). Concepts in social science : Feminism,

Gass, W. H.(1998) The concept of the character in fiction, Ed. Michael J. Hoffman. London: Duke University press

Gill, R. (1995). Mastering English literature. London: Macmillan Press.

Janovsky, A. Character in literature: definition, types \& development. Retrieved August 1 , 2018, from https://study.com/academy/lesson/characterin-literature-definition-typesdevelopment.html

Boggs, J.M. (1991). The art of watching film 3th ed., California: Mayfield Publishing Company.

Kaushik, N. (2011), August 13. Difference between qualitative data and quantitative data, Retrieved August 26, 2018, from https://www.differencebetween.net/science/ mathematics-statistics/difference-betweenqualitative-data-and-quantitative-data/

Kupperman, J. J. 1991. Character. New York: Oxford University Press

Laughlin, Thomas M. (1989). Literature the power of language. USA: Harcourt Brace Jovanica.

Moleong, L. J.(2005). Metodologi Penelitian Kualitatif. Bandung: PT Remaja Rosdakarya, 